\title{
University's Enterprise Architecture Design Using Enterprise Architecture Planning (EAP) Based on the Zachman's Framework Approach
}

\author{
Hari Supriadi, ST.,M.Kom ${ }^{1}$ \& Endang Amalia, ST.,MM ${ }^{1}$ \\ ${ }^{1}$ Departemen of Information System, University of Widyatama, Bandung, Indonesia \\ Correspondence: Hari Supriadi, ST.,M.Kom, Departemen of Information System, University of Widyatama, Bandung, \\ Indonesia. E-mail: hari.supriadi@widyatama.ac.id
}

Received: April 4, 2018

Accepted: September 28, 2018

Online Published: May 9, 2019

doi:10.5430/ijhe.v8n3p13

URL: https://doi.org/10.5430/ijhe.v8n3p13

\begin{abstract}
Information Technology Organization of an enterprise must have a framework of guidelines for the development of information system and adequate documentation of the systems and technology, so that further information could be given to devising a comprehensive and integrated system. Enterprise architecture is a conceptual blueprint that defines the structure and operation of an organization. There are numbers of processes or methodologies that can be used in the development of enterprise architecture products, one of them is an Enterprise Architecture Planning (Enterprise Architecture Planning/EAP) based on the Zachman's framework. Enterprise Architecture Planning is a compilation consisting of the following business model documents, IRC documents, data architecture applications, Data architecture blueprints, architectural blueprints, and the roadmap plan technology of Enterprise Architecture Planning.
\end{abstract}

Keywords: enterprise architecture, Zachman's framework, enterprise architecture planning (EAP), the blueprint of information systems, data architecture, application architecture, technology architecture, roadmap implementation plan, private company

\section{Introduction}

\section{A. Background}

Information Technology (IT) nowadays is not only a set of tools to organize activities but also part of an organization's strategy to achieve their goals. But the problem in this era is how to align between business strategy and technology strategy.

The following guidelines should be followed by an organization if they experience difficulty with carrying out the planning of enterprise information system architecture (enterprise architecture). This will provide a framework to make long-term information technology decisions that are supportive with the concerns of the organization. Enterprise Architecture is the organizing activities of data used and generated by organizations that include the purpose of the organization's business processes. Whereas the organization's information architecture (EA) is a blueprint that defines how IT and information management elements work together as a single unit. This framework would describe the infrastructure needed by the organization to achieve its goal and vision.

University is an academic organization that can assist with information technology to help various businesses. Its typical that an organizational form has its own character, so the shape of the required information system also must have its own character.

In many organizations that are in operation, various information system applications are used with a variety of technology platforms and supporting information technology devices. These systems are known as "legacy systems". Typically, these systems are separated from each other and consist of many "islands of data" within the organization. This dis-junction has a negative impact such as a low level of availability, consistency and effectiveness of the provision of data.

This paper will discuss the design of the enterprise architecture colleges using the Zachman framework approach with Universitas $\mathrm{XYZ}$ as the case study. 


\section{B. Universitas XYZ}

Universitas $\mathrm{XYZ}$ is a scientific institution which organizes academic or professional education programs in a number of scientific disciplines. Universitas XYZ that has the most diverse program of study, from the field of exact sciences to the social, from technology to language

The dynamics of research, innovation, and industry cannot be released by the growth of human civilization. In connection with industry, universities were reasonably likely to be a source of innovation for the sustainability of the industry. How to get the innovation is to do research. In regard to industry, research carried out is always associated with the technology in the sense tends to hardware or also the concepts for the growth of the service industry or even the knowledge services industry.

If formed and managed correctly, the university will qualify related, so the relationship between higher education, science, and technology in the industrialization of the country can be managed effectively and efficiently.

\section{Research Questions}

To analyze the needs of information technology and information systems, the writers ask questions as follows:

1. Why Enterprise Architecture is required by Universitas XYZ?

2. What are the benefits of Enterprise Architecture for Universitas XYZ?

3. What should be done so that organizations such as Universitas XYZ can be better defined?

4. Why Enterprise Architecture Design using Enterprise Architecture Planning (EAP) Based on the Zachman's Framework approach is used to define Universitas XYZ's Enterprise Architecture?

5. How to design information systems architecture for university such as Universitas XYZ?

D. Research Objectives

The objectives to design the information systems architecture are:

1. Analyze and document the Enterprise Architecture using EAP approach within the framework of Zachman's Framework. Final results are expected namely Enterprise Architecture documentation that describes the current state of Universitas XYZ.

2. Designing Enterprise Architecture and Business Informatics University of Indonesia in order to support the achievement of the goals of Universitas XYZ.

E. Scope and Limit to the Research

Scope of research's problem in the development of information systems architecture for university that will be developed, such as:

\section{Marketing and Promotion}

2. Academic Information System, includes:

a. Admissions (PMB).

b. Learning process

c. Evaluation and assessment of students portfolio

d. Graduates

3. Financial Information Systems

\section{HRIS}

The model that we will be built is a model of Enterprise Architecture based on the methodology used is approach to Enterprise Architecture Planning (EAP) in the Zachman's framework. The model will be built including:

1. Model data architecture

2. Model application architecture and

3. Model technology architecture

4. People Column or WHO

F. Research Methodology 
Architectural models development methodology that we will be used is Enterprise Architecture Planning based on the Zachman's framework, stages of the development are:

1. Planning Initiation

2. Business Modeling

3. Current systems and Technology

4. Data Architecture

5. Applications Architecture

6. Technology Architecture

7. Implementation Plan

\section{People or WHO}

\section{Literature Review}

A. The Literature Architecture

Understanding the architecture here is not just limited to general knowledge related to physical construction, but also in the context of business and architecture for software engineering, following some sense related architecture:

1. Architecture (Architecture) are the components of a system consisting of network, hardware and software are structured. (Electronic Industry Association, 2008)

The overall design of this type of construction of both physical and context, real or virtual. (ICH Architecture Resource Center, 2008) and a tangible manifestation of the implementation results.

2. From the definition above we can therefore conclude what basically describes the architecture of the system construction form embodied in a model (blueprint) as viewed from several perspectives.

B. Enterpris

Here are some definition of enterprise:

1. Organizations that support the business environment and the mission that has been set.

2. The proper functioning of the overall component of an organization that operates under the control of the organization.

Enterprise is not only a profit-oriented organization/profit (profit oriented) but also non-profit organizations such as educational institutions. Enterprise can be in an organization as a whole or a part of the organization. (Electronic Industry Assocation, 2008)

C. Enterprise Architecture

Definition of Enterprise Architecture, such as:

1. Descriptive representation (model) that is relevant to describe an enterprise and what should be produced to meet the needs of management or organization (Electronic Industry Assocation, 2008).

2. The mapping of blueprint that show the relationship between components and all the people working in the company consistently to improve cooperation/collaboration, and coordination among them (Ward, John and Peppard, Joe, 2002).

3. A mechanisms to ensure information technology resources of an organization might be in line with the strategy of the organization (Riverton Corp., 2008)

D. Zachman Framework (ZF)

Zachman Framework or ZF is a classification scheme for organizing artifacts enterprise (Jurnal Pemamfaatan Enterprise Architeture Planning Untuk Perencanaan Strategis Sistem Informasi, Krisdanto Surendro, 2007). ZF consists of 6 columns and 6 rows. Each column represents the focus, abstraction, or enterprise architecture topics, namely: data, function, network, people, time, and motivation. Each line represents the following perspectives:

1. Perspective Planner: establish the context, background, and destination.

2. Perspective Owner: establishing conceptual model of the enterprise. 
3. Designer Perspective: establish a model of information systems and bridge the desirable things owners and things that can be realized technically and physically.

4. Perspective Builder: defining the technical and physical design that is used in overseeing the technical and physical implementation.

5. Perspectives Subcontractors: assign roles and reference for the responsible parties to undertake the construction of information systems.

6. Functional Perspective: represent the perspective of the user

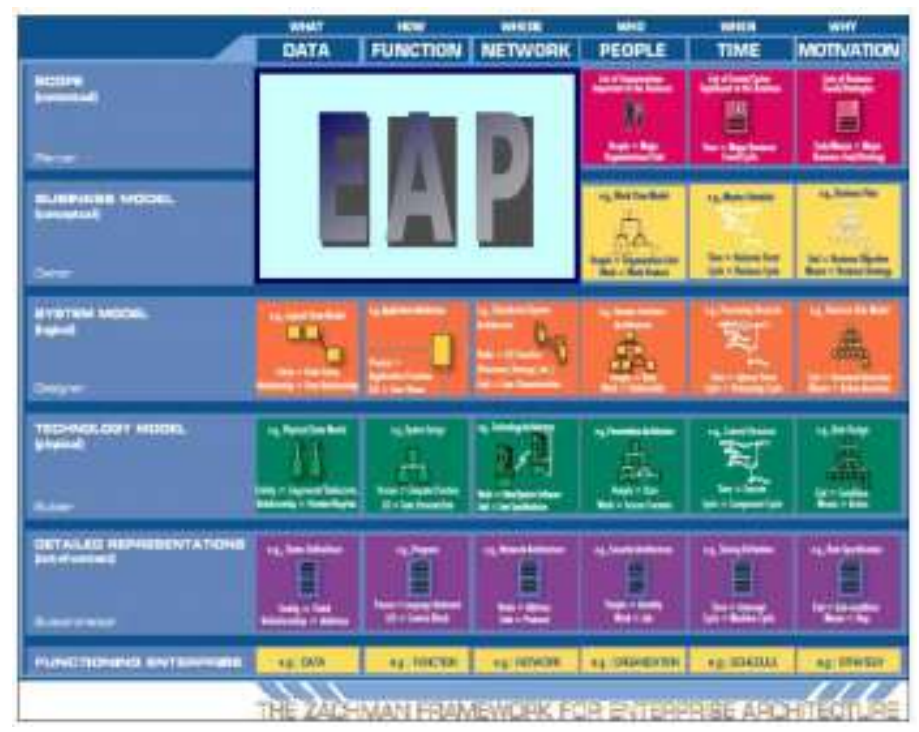

Figure 1. Zachman Framework (ZF)

E. Enterprise Architecture Planning (EAP)

EAP is a method used to build the information architecture. According to Steven H Spewak, EAP is a business definition and architecture, not the business design and architecture.

EAP is an architecture in data architecture, application and technology needed to support the organization's business. Steven H Spewak stated that the architecture here is intended like a blueprint, drawing, or model.

Components of the EAP according Spewak basic use of two layers of John Zachman's framework, namely of reviews planner and owner. EAP component can be described as picture below:

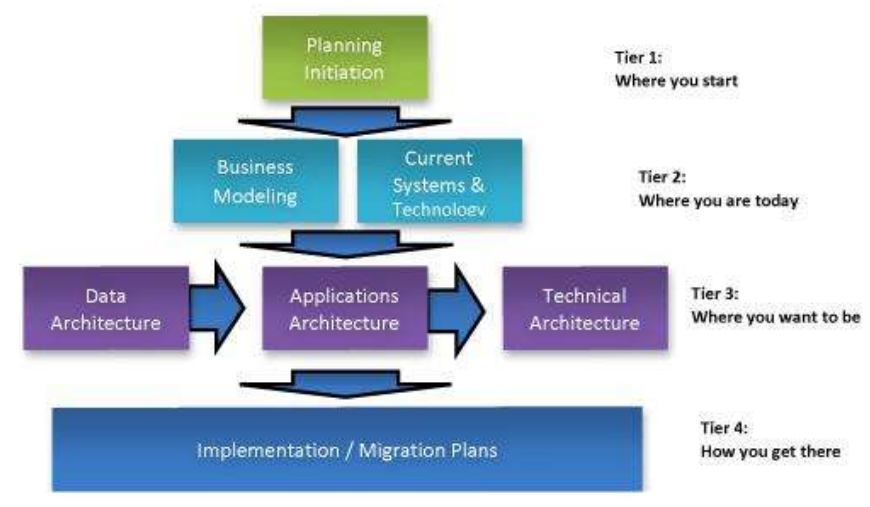

Figure 2. Enterprise Architecture Planning (EAP) Components 
F. Design of Enterprise Architecture Planning Initiation

At the initiation stage of planning there are four stages that must be passed, such as:

1. Defining the Scope and the goal of the EAP.

2. Defining the vision of the company

3. Election Planning Methodology Approach

4. The use of computer resources

From above, then we can start to define the organization's function business.

\section{Data Collection and Analysis}

A. Identifying and Defining Business Functions

Based on observations in the company, there are seven major functions that occur in Universitas XYZ namely:

1. Marketing and Promotion

2. Admissions

3. Learning Centre Process

4. Graduate Students

5. Financial Management and Accounting

6. Human Resource Management and General

7. Academic Section

Identification of main and supporting activities of Universitas XYZ can be indicated by using the value chain of Michael E.Porter that looks like the image below:

Candidates Entity Data

Candidates entity based on existing business functions in the organization that has been described previously, in order to obtain candidate entities as follows:

1. Admissions

2. Learning Centre Process

3. Graduate Students

4. The Bureau of Public Administration, Finance and Human Resources

5. Administrative Bureau of Academic and Student Affairs

6. Assistant Dean

\section{Program}

8. Head of the Laboratory

Definition Entity Sets, Attributes and Relationships

The depiction of the relationship between conceptual data entities using E-R diagram looks like the images below:

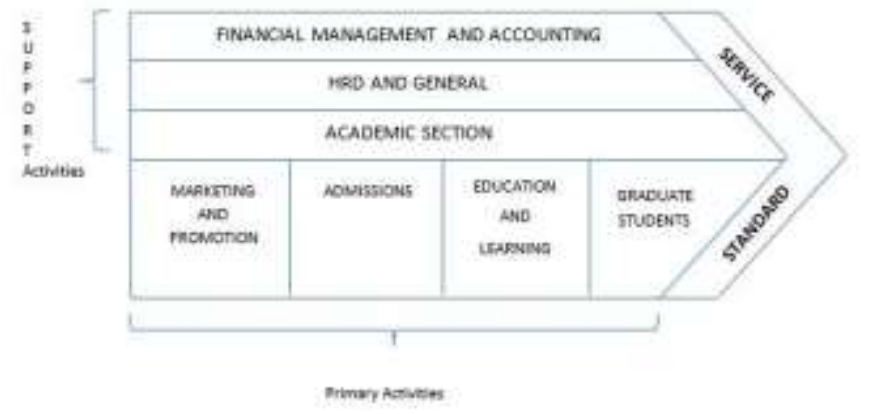

Figure 3. Universitas XYZ 's Value Chain 
B. Business modeling

Stages in the development of Universitas XYZ's business models, are:

1. An overview of the organizational structure

2. Identify Business Functions and market shared

3. Business Function Hierarchy Chart of Universitas XYZ

4. Process Flow Information System

C. Existing Systems Architecture and Technology

The process that is being done at this stage is to make efforts to know the system architecture and technology that are running by creating a collection of IRS (Information Resource Catalog) and architectural schemes underway in Universitas XYZ.

Data Architecture

Data architecture aims to define the data that will be used to develop and build the application architecture. Based on existing measures in the EAP, data architecture defines two (2) things:

\section{Candidates Entity Data}

2. Entity Sets, Attributes and the relationship

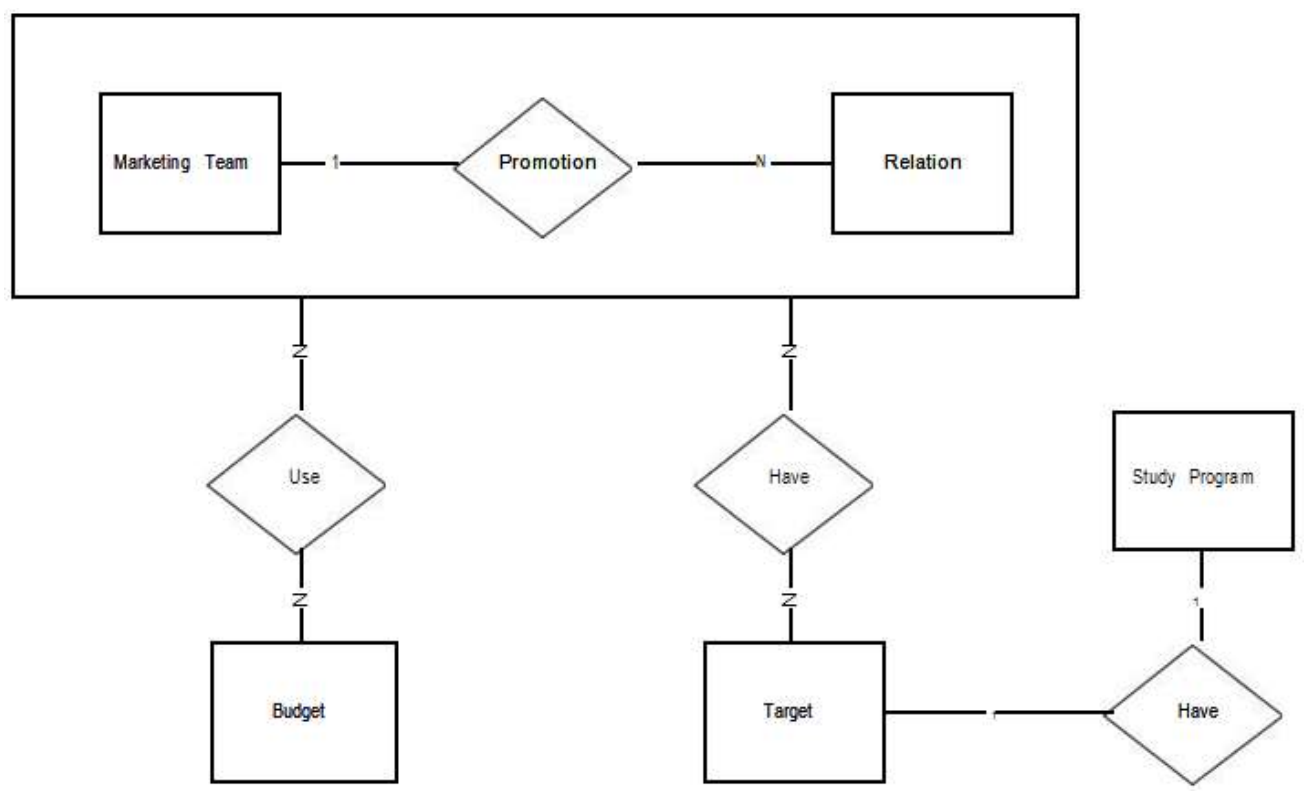

Figure 4. Marketing and Promotion's Diagram 


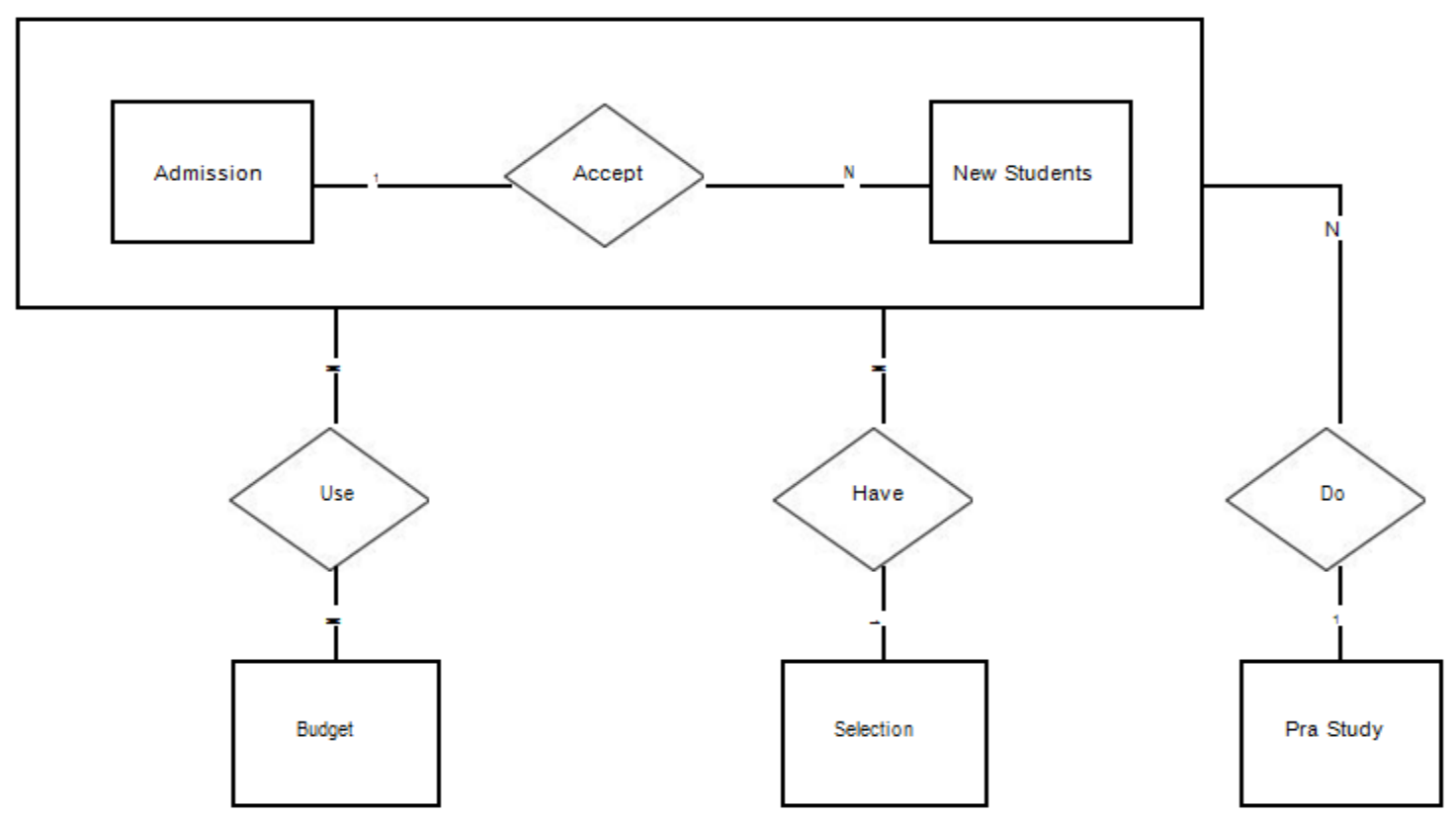

Figure 5. Admission's Diagram

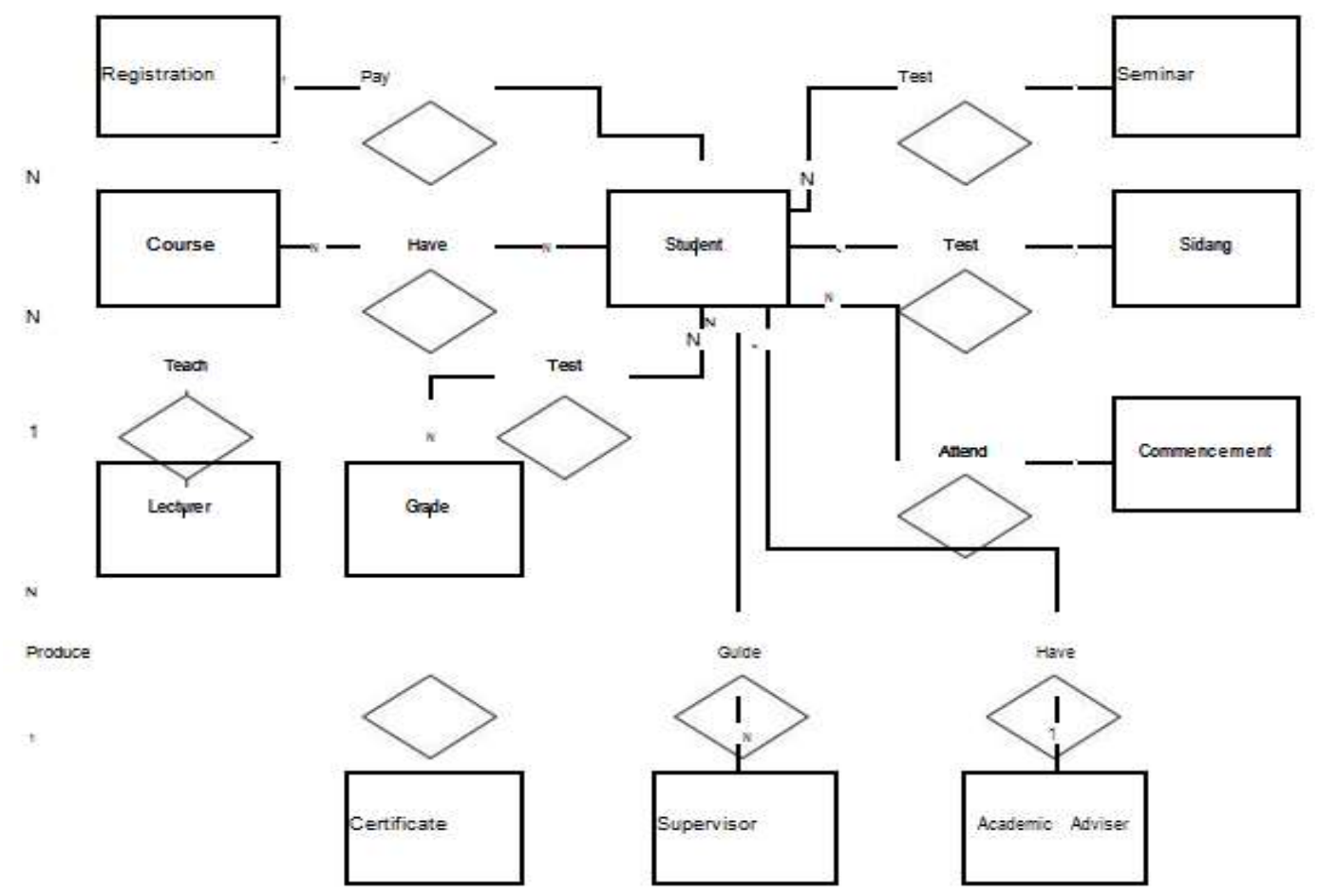

Figure 6. Learning Centre's Diagram 


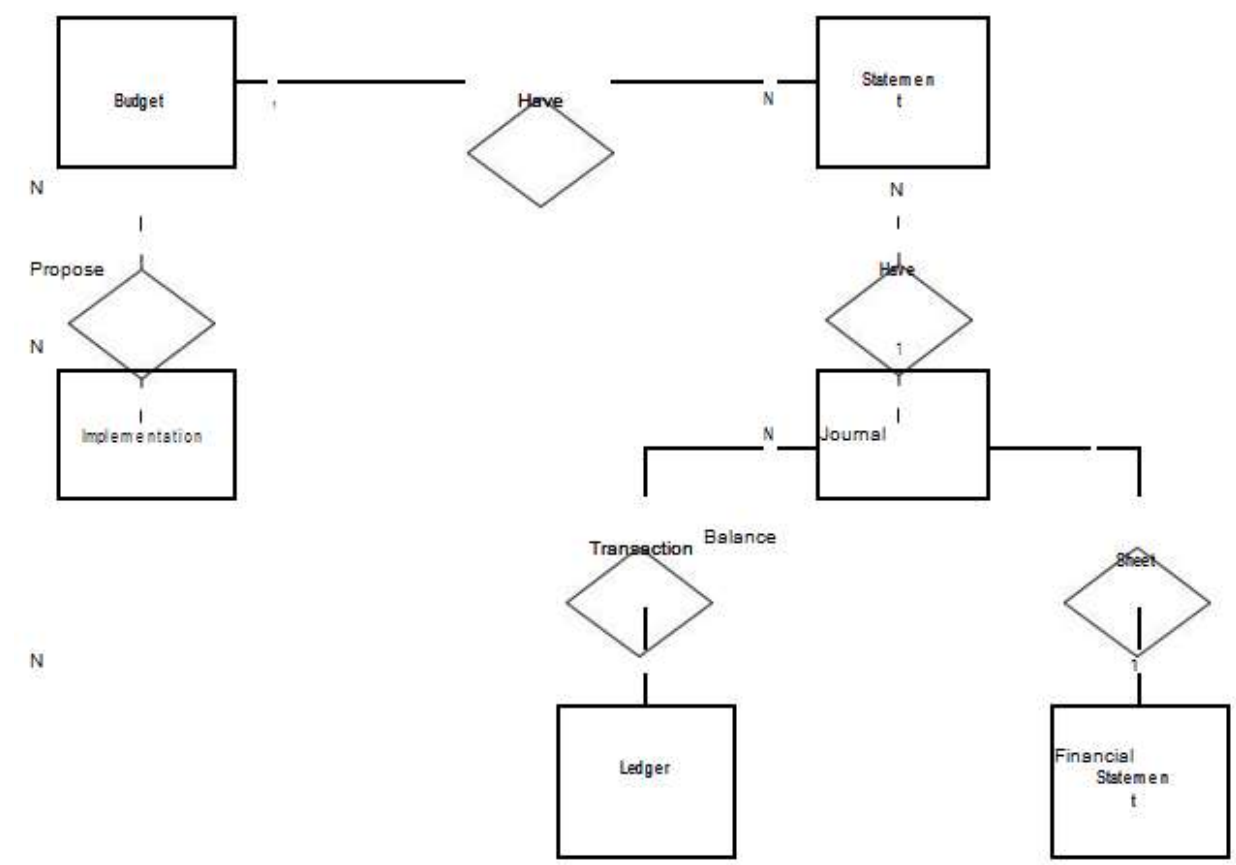

Figure 7. Financial Management and Accounting's Diagram

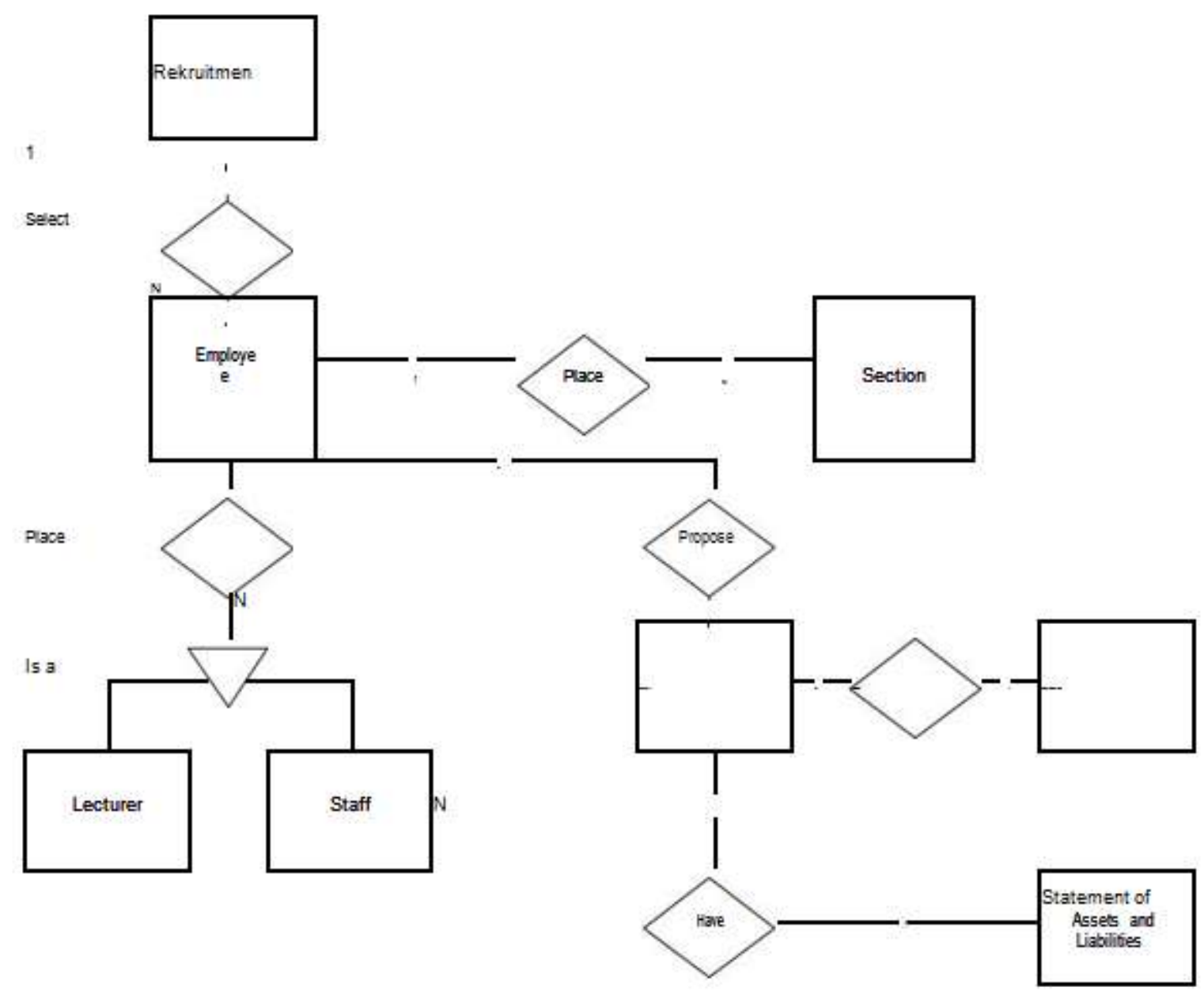

Figure 8. Human Resource Management and General's Diagram 
Application Architecture

Steps being taken to make the architecture of the application required by the organization, as mentioned below:

1. Candidate application

2. Relationship between application and business function

3. Relationship between application and organization

Table 1. System Candidate

\section{STATE OF}

\section{CANDIDATE}

\section{SYSTEM}

\section{Admissions}

2. Processing Selection Log

3. Registration of New Students Plan

4. Lecture Schedule Plan

5. Processing Study Plan

6. Change Study Plan

7. Processing Academic Leave administration and

Quitting Students

8. The enforcement of student tests

9. Payment of Seminar, final work and

Existing system Commencement

The enforcement of Seminar and final

10. work

11. Processing of Academic Transcripts

Recording of Receipts and

12. Expenditures

Organization

13. Recording Transactions

14. Financial Statements

15. Inventory of Assets Organization

16. Usage Report Assets Organization

17. Statement of Assets and Liabilities

18. Organizational Asset Report

19. Online admission

System under

20. Online library

development

21. HRD Report

22. Budgeting Report

23. Development of Skill and Knowledge

Planned system 24. Certificates Production 


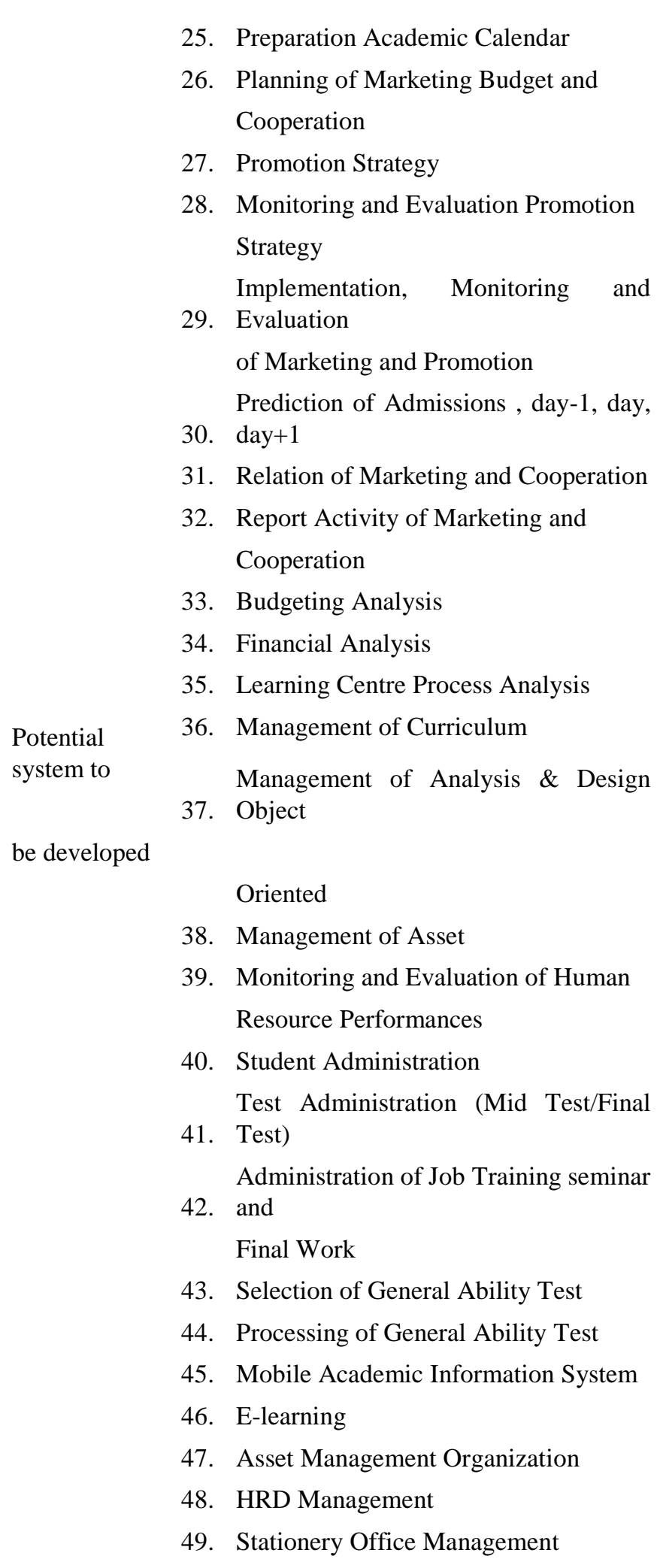


Architecture Technology

After identification of the data architecture and application architecture, the next step which proposes the development of a technology architecture that is owned in order to improve system performance, as shown below:

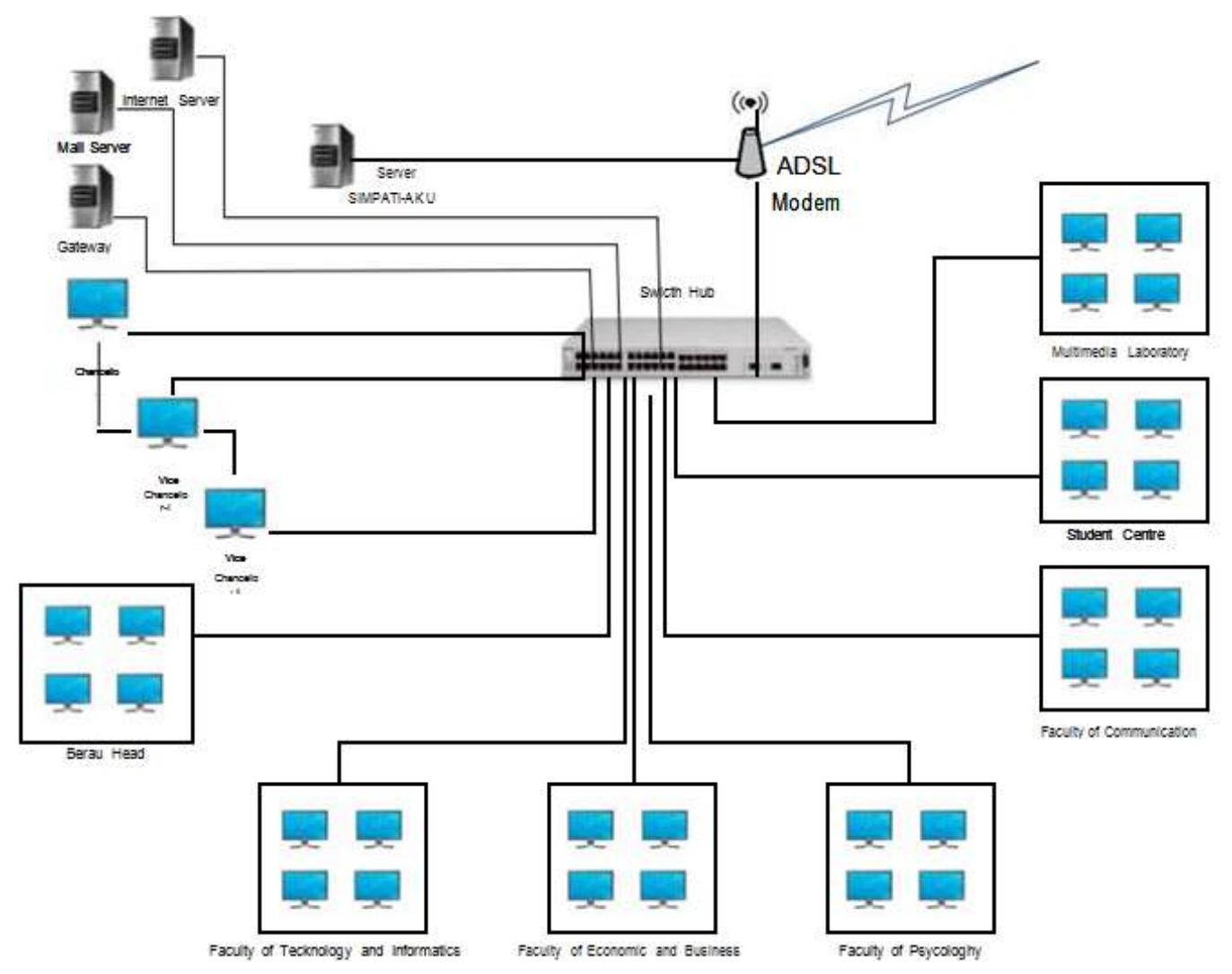

Figure 9. Universitas XYZ's Technology Architecture

Implementation Planning

Implementation planning is an important part of the EAP, in which all planning applications to be built can be applied according to the time, cost and according to need.

Table 2. Sequence Planning of Application Implementation

\section{CONDITION}

\section{STAGE SEQUENCE PRIORITY STATE}

1. Admission of New Students
Online
Academic Information
2. Systems
Online $\quad$ Under development
3. Online library process
4. Budgetary Marketing and
Promotion
5. Payment of Tuition Fees
6. Marketing and Promotion's Potential to be


Monitoring and Evaluation

developed

7. E-Learning

Preparing academic

8. calendar

To be planned

Administration of Job

9. Training

seminar and Final Work

Students Centre Proces

10. Analysis

II

Potential to be

11. Curriculum management

$$
\text { developed }
$$

12. HRD Management

Monitoring and Evaluation

13. of

Human Resource

Performances

14. Creation of certificate To be planned

15. Management of Analysis \&

Design Object Oriented

Stationery Office

III

16. Management Potential to be

Management of Fixed

17. Assets developed

and Current Assets

18. Stationery Office Reporting

19. Reporting Budget To be planned

20. Financial Budgeting Potential to be

IV 21.Budget Analysis developed

Organization Asset

22. Management

Research and Development 23. of

To be planned

Human Resource

Performance 


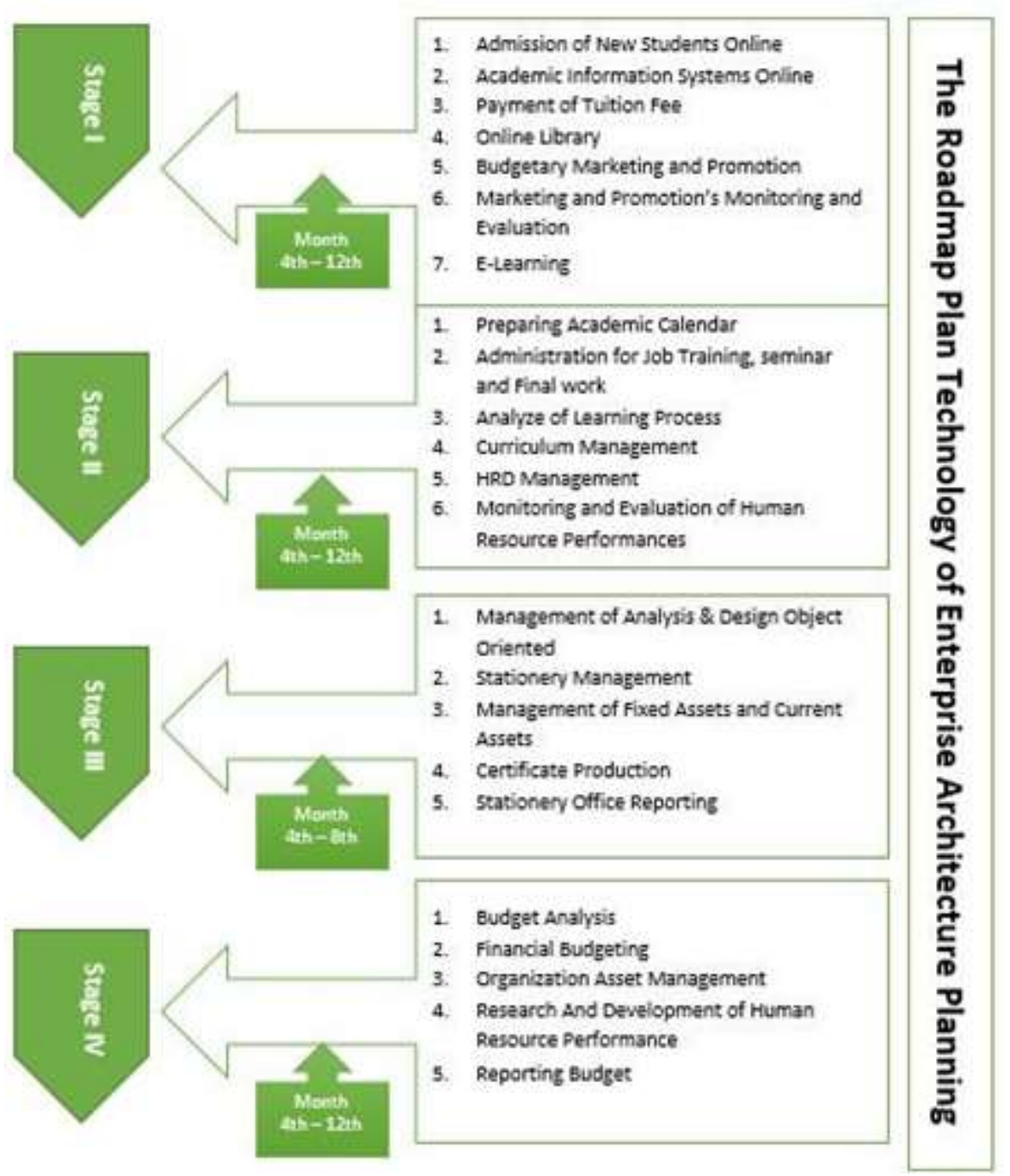

Figure 10. The Roadmap Plan Technology of Enterprise Architecture Planning

D. Implementation of Critical Success Factor and Guidelines Recommendation for Information System Construction and Development

The success of the implementation will be influenced by many factors, and therefore the need identified the factors that determines the success of the implementation of this system, described as below:

1. Strong commitment and consistent also direct involvement will greatly help good implementation.

2. Approval of the implementation plan.

3. Develop SOP

4. Availability of resources, technology and infrastructure.

5. Develop of understanding, skills and knowledge of human resources through special training.

E. Zachman Framework (People Column or WHO)

In the field of who, will discuss the human resources play an important role in Universitas XYZ. The parts described are:

\section{Scope}

2. Enterprise Model

\section{System Model}

4. Functional System 


\section{Conclusions}

\section{A. Conclusions}

Based on the stage that has been done in the previous chapter, it can be concluded as follows:

1. Proposed Strategy and analysis high potential applications for institution (organization) is needed to formulate medium and long term policy in accordance with the Master Plan Development's organization.

2. The results of SWOT analysis helps identify where the Universitas XYZ exact nowadays, both with regard to resources that can be utilized and the problems that will not be resolved yet. By doing this Universitas XYZ can identify where or when new resources, skills or new partners will be needed.

3. The results obtained that the existing application to date is 20 (twenty) applications that supports the organization's business functions.

4. To generate roadmap implementation plan which can be used as a reference in the development of applications that support the business functions of the organization. Roadmap implementation plan suggested by the EAP is based on data-driven, such as applications that generate data should be built first followed by applications using the data.

B. Suggestion

As a reference to create the next EAP, we submitted some suggestions, as follows (Jabarullah et al., 2019):

1. Selection of the next application should be appropriate and support the organization's business functions so that the benefits that will be generated optimal.

2. Commitment management should always be focused and consistent on the development of this information system in order to achieve organizational goals faster and according to expectations.

3. Socialization construction or development of information systems must be provided to each unit of organizational that can provide very useful contribution to the next development.

4. The next of chosen application should be appropriate and support the organization's business functions so that the benefits that will be generated optimal.

\section{References}

Alter, Steven. (2012). Information System (The Foundation of E-Business). Prentice Hall.

Cavico, F. J., Mujtaba, B. G., Muffler, S., Samuel, M., \& Polito, N. M. (2017). Restaurant Liability for Contaminated Food and Beverages Pursuant to Negligence, Warranty, and Strict Liability Laws. Global Journal of Social Sciences Studies, 3(2), 63-100. https://doi.org/10.20448/807.3.2.63.100

Dunst, C. J., Raab, M., Embler, D., \& Roberts, K. (2018). Developing Evidence-Informed Early Childhood Intervention E-Learning Lessons, Performance Checklists and Practice Guides. Journal of Education and e-Learning Research, 5(4), 242-248. https://doi.org/10.20448/journal.509.2018.54.242.248

Hussein, L. M. (2017). The Effectiveness of Teaching Educational Research Course on the Development of Scientific Research Skills, Academic and Personal Integrity among Female Students of Al-Qassim University. International Journal of Asian Social Science, 7(5), 392-409. https://doi.org/10.18488/journal.1.2017.75.392.409

Ipole, P. A., Agba, A. O., \& Okpa, J. T. (2018). Existing working conditions and labour unions agitations in cross river state civil service, Nigeria. Global Journal of Social Sciences Studies, 4(1), 39-51. https://doi.org/10.20448/807.4.1.39.51

Jabarullah, N.H., Shabbir, M.S., Abbas, M., Siddiqi, A.F. \& Berti, S. (2019) Using random inquiry optimization method for provision of heat and cooling demand in hub systems for smart buildings, Sustainable Cities and Society, 47, 101475. https://doi.org/10.1016/j.scs.2019.101475

Jafari, S., Jafari, S., \& Kafipour, R. (2018). Iranian Housewives Motives for English Language Learning from a Discursive Psychology Perspective. International Journal of English Language and Literature Studies, 7(4), 138-149. https://doi.org/10.18488/journal.23.2018.74.138.149

Jeremiah, K. (2018). Role of British Colonial Education on Reduction of Illiteracy for Wasukuma 1918-1961: A Case of Shinyanga District Tanzania. International Journal of Educational Technology and Learning, 4(1), 25-33. https://doi.org/10.20448/2003.41.25.33

Jurnal Penelitian, Falahah dan Dewi Rosmala, Penerapan Framework Zachman Pada Arsitektur Pengelolaan Data 
Jurnal Penelitian, Kuswardani Mutyarini, S.T, Dr. Ir. Jaka Sembiring, Arsitektur Sistem Informasi Untuk Institusi Perguruan Tinggi di Indonesia, Mei 2006.

Karayama, S. (2018). School Administrators Who Serve in Different Institutions Ethical Dilemmas and Their Attitudes towards These Dilemmas. Asian Journal of Education and Training, 4(3), 201-209. https://doi.org/10.20448/journal.522.2018.43.201.209

Keskin, Ö., \& Akdeniz, H. (2018). Investigation of Aggression Levels of University Students (Kocaeli University Case). Asian Journal of Education and Training, 4(3), 186-196. https://doi.org/10.20448/journal.522.2018.43.186.196

Keskin, Ö., \& Korkutata, A. (2018). Reviewing Academic Motivation Levels of Students Study in Different Faculties in Terms of Certain Variables (Sakarya University Case). Journal of Education and e-Learning Research, 5(2), 208-216. https://doi.org/10.20448/journal.509.2018.53.208.216

Khan, S. N., \& Ali, E. I. E. (2017). The moderating role of intellectual capital between enterprise risk management and firm performance: A conceptual review. American Journal of Social Sciences and Humanities, 2(1), 9-15. https://doi.org/10.20448/801.21.9.15

Kip'ngetich, K. J., Osman, A. A., \& Ali, M. M. (2018). John Deweyl's Experimentalism Philosophy and its Claim to the Kenyan Education System. Global Journal of Social Sciences Studies, 4(1), 30-38. https://doi.org/10.20448/807.4.1.30.38

Kobylinski, C. (2018). The Benefits of Using Facebook Live for Listening Activities in A Korean University EFL Classroom. International Journal of Educational Technology and Learning, 4(2), 40-45. https://doi.org/10.20448/2003.42.40.45

Kobylinski, C., \& Prasad, R. (2018). English for Academic Purposes in the Korean University Context: Teachers' Opinions on What is Being Taught, How it is Being Taught, and Possible Improvements. International Journal of Educational Technology and Learning, 4(2), 58-67. https://doi.org/10.20448/2003.42.58.67

Köse, B. (2018). Does Motivational Music Influence Maximal Bench Press Strength and Strength Endurance?. Asian Journal of Education and Training, 4(3), 197-200. https://doi.org/10.20448/journal.522.2018.43.197.200

Kweka, K. H., \& Ndibalema, P. (2018). Constraints hindering adoption of ICT in government secondary schools in Tanzania: The case of Hanang District. International Journal of Educational Technology and Learning, 4(2), 46-57. https://doi.org/10.20448/2003.42.46.57

Kyrychenko, V. (2018). Indonesias Higher Education: Context, Policy, and Perspective. Asian Journal of Contemporary Education, 2(2), 159-172. https://doi.org/10.18488/journal.137.2018.22.159.172

Lawal, O., \& Samy, M. (2017). Perception of Stakeholders in Funding of Medical Education in Nigeria. International Journal of Asian Social Science, 7(6), 521-534. https://doi.org/10.18488/journal.1.2017.76.521.533

Lupu, C. (2017). The Relationship between Types of Intelligence and Study Profile Options. American Journal of Education and Learning, 2(1), 23-33. https://doi.org/10.20448/804.2.1.23.33

Marangoz, I. (2018). The Determination of the Relationship between Somatotypes and Speed of Sub-Elite Athletes. Asian Journal of Education and Training, 4(3), 220-223. https://doi.org/10.20448/journal.522.2018.43.220.223

Marangoz, I., \& Var, S. M. (2018). The Relationship among Somatotype Structures, Body Compositions and Estimated Oxygen Capacities of Elite Male Handball Players. Asian Journal of Education and Training, 4(3), 216-219. https://doi.org/10.20448/journal.522.2018.43.216.219

Mokhtar, S. B. (2017). Teaching-Learning Model of Islamic Education at Madrasah Based on Mosque in Singapore. $\begin{array}{lllll}\text { International Journal of Asian Social } & \text { Science, } & 7(3), & \text { 218-225. }\end{array}$ https://doi.org/10.18488/journal.1/2017.7.3/1.3.218.225

Morgan, B. M., \& Alcocer, L. F. (2017). Descriptive Comparison of Hispanic Doctoral Students (2007-2014) with Carnegie Initiative of the Doctorate National Survey Results. American Journal of Education and Learning, 2(1), 14-22. https://doi.org/10.20448/804.2.1.14.22

Mungwari, T. (2018). Media framing of ZANU PF Internal Succession Struggles: Mnangagwa and the Military Factor. American Journal of Social Sciences and Humanities, 3(1), 1-21. https://doi.org/10.20448/801.31.1.21 
Nair, S. M., \& Hui, L. L. (2018). An Analysis of Common Errors in ESL Descriptive Writing among Chinese Private School Students in Malaysia. International Journal of Education and Practice, 6(1), 28-42. https://doi.org/10.18488/journal.61.2017.61.28.42

Okendo, O. E. (2018). Strategies Used to Enhance Parent Involvement on Performance of Early Childhood Education in Kisii, Nyamira and Homabay Counties, Kenya. International Journal of Educational Technology and Learning, 4(1), 1-7. https://doi.org/10.20448/2003.41.1.7

Olajoke, A. S., \& Olamide, I. (2017). Challenges and Prospects of Implementation of Teaching of English to Speakers of Other Languages (TESOL) Approaches in Nigeria. American Journal of Education and Learning, 2(2), 153-158. https://doi.org/10.20448/804.2.2.153.158

Operasional (Studi Kasus SBU Aircraft Service, PT.Dirgantara Indonesia), Juni 2010.

Planning Guide), International Business Machines Corporation, 1981.

Porter, Michael E. (1985). Competitive Advantage: Creating and Sustaining Superior Performance for Analyzing Industries and Competitor. The Free Press.

Riverton Coprporation, http://www.riverton.com, Architecture Practice, Maret 2008 ?id=301, 2004.

Silberschatz Abraham, Korth Henry F, Sudarshan S., Database System Concept, Fourth Edition, The McGraw-Hill Companies, Inc., 2002.

Uzun, N. B., Aktas, M., Asiret, S., \& Yormaz, S. (2018). Using Generalizability Theory to Assess the Score Reliability of Communication Skills of Dentistry Students. Asian Journal of Education and Training, 4(2), 85-90. https://doi.org/10.20448/journal.522.2018.42.85.90

Ward, John \& Peppard, Joe. (2002). Strategic Planning for Information System. John Wiley \& Sons, Inc.. 